\title{
Developing Pro-European Environmental and Climate Policy for Ukraine: Institutional Challenges, Appropriate Translation and Legal Compliance Scheme
}

\author{
Anastasiia Kraskovska \\ Department of Political Sciences “Jean Monnet”, University of Campania Luigi Vanvitelli, Caserta, Italy
}

Email address:

anastasiia.kraskovska@gmail.com

\section{To cite this article:}

Anastasiia Kraskovska. Developing Pro-European Environmental and Climate Policy for Ukraine: Institutional Challenges, Appropriate Translation and Legal Compliance Scheme. International Journal of Law and Society. Vol. 1, No. 2, 2018, pp. 64-71.

doi: $10.11648 /$ j.ijls.20180102.12

Received: October 29, 2017; Accepted: December 12, 2017; Published: January 16, 2018

\begin{abstract}
Ukraine's aspiration for European Union integration has been defined in national policies, laws and international treaties since 1994: within the Partnership and Cooperation Agreement framework between Ukraine and the European Union (1994), the Eastern Partnership (2009), the Law of Ukraine "On the Principles of Internal and Foreign Policy" and many others. However, all these documents were of a predominantly advisory nature, without establishing a strategic need for approximation of Ukrainian legislation to EU norms, especially in the field of environmental protection and climate change mitigation. The Association Agreement between Ukraine and the European Union, signed in 2014, aims to gradually bring Ukrainian legislation in line with objectives enshrined in the EU law, which envisages "transposition" of EU law norms into the Ukrainian legal system. This paper provides detailed assessment of main stages and achievements of Ukraine's approximation process to the European environmental law (both in terms of Eastern European specifics of environmental regulation and national challenges), and puts emphasis on institutional challenges, environmental and climate governance, proficient translation of European legislation and key requirements for public administration, related to environmental laws' approximation.
\end{abstract}

Keywords: Acquis Communautaire, Approximation, Association Agreement, Climate Change, Environmental Legislation, European Union, Ukraine

\section{Introduction}

Fulfillment of the Association Agreement by Parliament and Government of Ukraine includes a number of policies and other documents, related to approximation of environmental laws to EU legislation. The basis for the cooperation of the Government of Ukraine and the European Commission is laid down in the Association Agenda practical tool for joint training which promotes the full implementation of the Association Agreement. Ukraine and the European Union have set priorities of Association Agenda, which complement the obligations of the parties under the Association Agreement for its full implementation [1].

Since the ratification of the Framework Convention and the Kyoto Protocol in Ukraine is still not accepted in law any legal act in the area of climate change. During the last several years the state made its first steps on the legal settlement of the climate change issue in Ukraine and anthropogenic greenhouse gas (GHG) emissions by developing a draft law of Ukraine "On the regulation and control of emissions and removals of greenhouse gases," "On the environmental market of Ukraine", "On regulation of energy saving ","On greenhouse gases".

All these projects have a common goal - to determine the legal and organizational basis for preventing and mitigating climate change effects, Ukraine's commitments under the United Nations Framework Convention on Climate Change (UNFCCC) and the Kyoto Protocol and even some overlap in content. However, the emphasis of these drafts is not on reducing greenhouse gas emissions and international emissions trading and joint implementation projects. No independent state initiative has been created to reduce the negative impact on the climate. However, these laws are still 
not accepted, and the first two of them - "instructed to consider a different project".

\section{Analysis of National Environmental and Climate Legislation}

\subsection{Main Ukrainian Legal Acts on Environmental Protection}

As to draft Law of Ukraine "On the regulation and control of emissions and removals of greenhouse gases," national action plan for the Kyoto Protocol implementation provides for the approval of this regulation. However, due to its substantial similarity to the draft law "On regulation of energy saving", it has been decided to consider the draft "On regulation of energy saving." Draft Law of Ukraine "On greenhouse gases" sets out important tasks aiming climate change prevention and mitigation, Ukraine's commitments under the UNFCCC and the Kyoto Protocol. However, it was removed from consideration.

It is necessary to develop a separate section in the Law of Ukraine "On Air Protection", which will regulate the general requirements for climate change and settlement rules, standards, regulations, permits and limits on greenhouse gas emissions, their monitoring and accounting.

Regarding the Law of Ukraine "On Environmental Protection", it defines the legal, economic and social foundations of environmental protection for present and future generations. Also, according to the preamble, Ukraine carries out on its territory an ecological policy aimed at maintaining a secure livelihood living and inanimate environment, protection of life and health from the negative effects caused by environmental pollution, achieving a harmonious interaction between society and nature, protection, conservation, sustainable use and restoration of natural resources, prevent and eliminate the negative impact of economic and other activity on the environment [2]. The relevant changes are needed for the proper regulation of relations and for climate change mitigation. Improving the accountability for violations in the sphere of human influence on climate change should be done by installing some of offenses in the Code of Ukraine on Administrative Offences and the Criminal Code of Ukraine.

\subsection{Subordinate Legal Acts and Policy Documents}

Equally important in regulating climate change in Ukraine are subordinate legal acts, and there are many which deeply regulate the actual issues in this area (e.g. according to the CMU Resolution "On the climate program of Ukraine" (Climate Programme) of 28 June 1997 № 650, the climate is recognized as one of the main natural resources, which depends on the living conditions and human activities, directions and level of economic development) [3].

In Ukraine, the government order was approved by the National Action Plan for the implementation of the Kyoto Protocol (hereinafter - the National Plan) of 18 August 2005 № 346-p. (with amendments of 05 March 2009). National Plan contains a number of measures aimed at the implementation of international commitments on climate change, the list of perpetrators of these measures and the period over which they are to be performed. Most of these measures have not been implemented in these terms in the National Plan, and therefore not sold, but were provided for the following measures:

1. Development of the organization and conduct monitoring of human-made greenhouse gases emissions (deadline expired in December 2009),

2. Improvement of methodological and information support, which is used to determine the amount of greenhouse gases in sectors with international requirements and display information about a volume on the results of state statistical observations in the report and statistical documentation (deadline expired in December 2009),

3. Development of methods for determining the amount of absorption of greenhouse gases (deadline expired in 2009-2010),

4. Preparation and approval of the National Plan of allocation of permissions for anthropogenic emissions by sources of greenhouse gases (deadline expired in June 2009).

Designed, but still have not been adopted the national action plan for climate change mitigation. Despite the missed deadlines, the draft of the National Action Plan on climate change adaptation has been published for public discussion in October 2011. A large number of regulations adopted by the regulatory acts mainly regulate certain issues in the field of climate change.

\subsection{Joint Implementation Projects, Bilateral Agreements and Carbon Trading Regulations}

Other types of Ukraine's environmental obligations are presented in Figure 1.

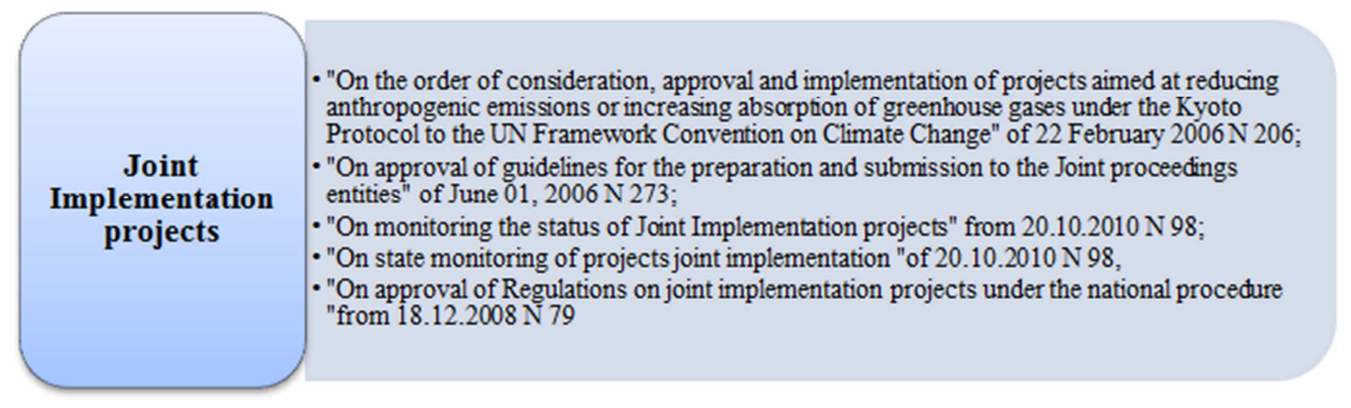



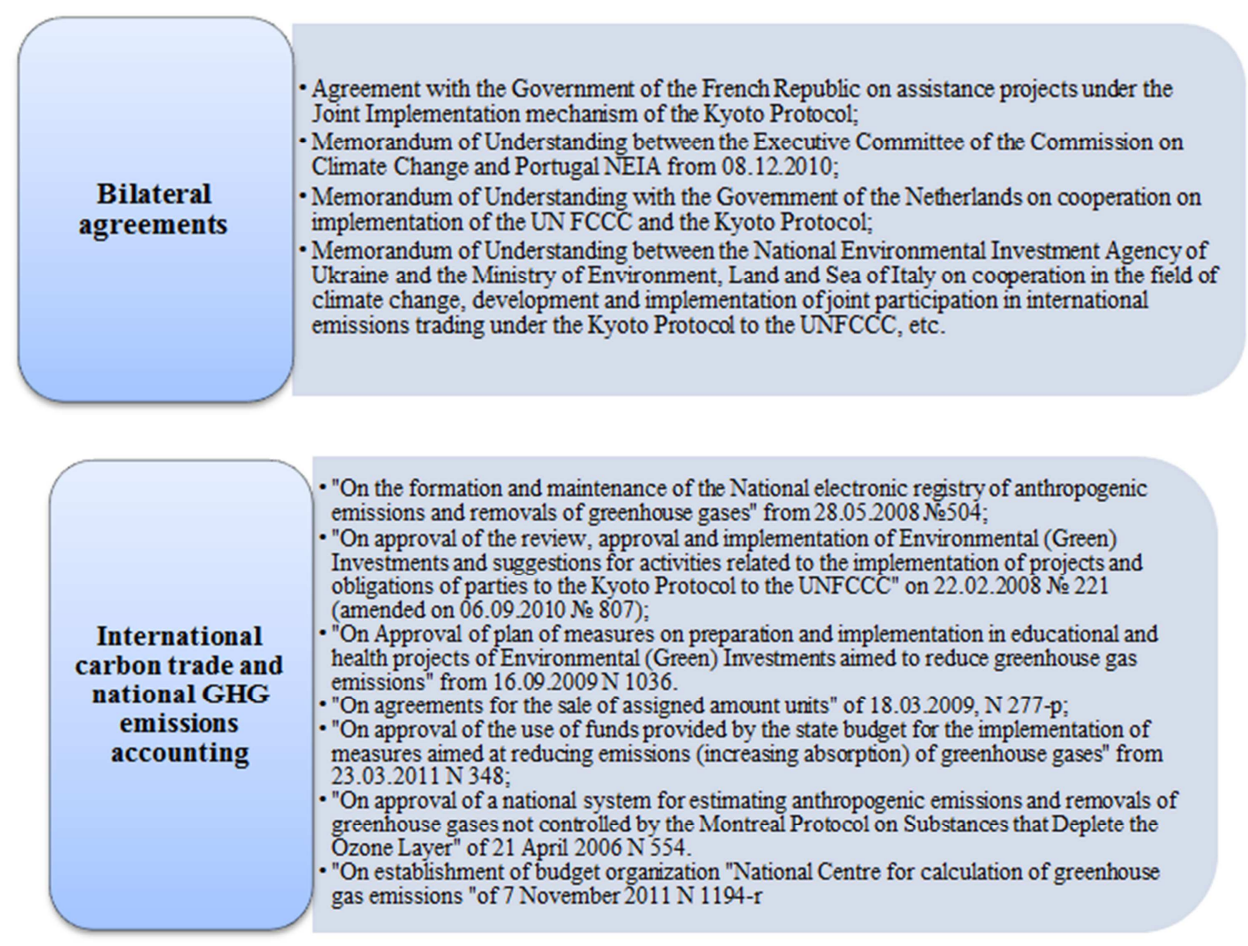

Figure 1. Main national obligations in the field of environmental protection.

\section{Developing Ukraine's National Environmental Policy, Based on European Standards}

\subsection{Main Approximation Measures and Directions}

Ukrainian actions and legislation for climate change mitigation coincides with improved economy and increased competitiveness:

1. Development of energy efficiency and alternative energy sources to help reduce dependence on imported energy and contribute to reducing emissions of other pollutants emitted from fuel combustion. According to statistics from the International Energy Agency, Ukraine has one of the most energy intensive economies in the world.
2. By ratifying the Kyoto Protocol, Ukraine got an opportunity to raise additional funds to implement projects for the greenhouse gas emissions' reduction. Public and private companies can receive partial funding for the enterprises' modernization through greenhouse gas emissions' further reductions for the Joint Implementation (JI) mechanism.

3. By signing the United Nations Framework Convention on Climate Change and ratification the Kyoto Protocol Ukraine has assumed certain obligations to implement policies to reduce greenhouse gases emissions. It is among the twenty largest polluters of the global $\mathrm{CO}_{2}$ emissions and therefore also responsible for the consequences of global climate change [4].

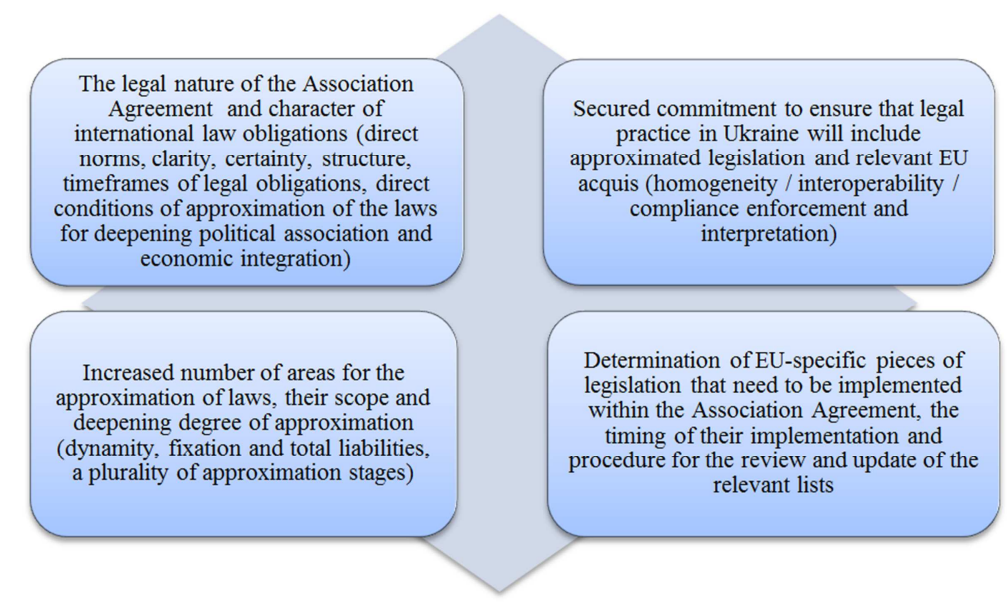

Figure 2. Ukraine's commitments in the environmental laws' approximation according to the Association Agreement. 
Ukraine's commitments according to the Association Agreement, provisional application of certain provisions, especially regarding approximation of legislation will require a fundamental change in approach and tools in this area [5, 6]. This is due primarily to the following factors (Figure 2):

Thus, it is time to address the pressing problem - raising priority of legislative approximation, and identify it as part of state policy in the respective area, carried out by a comprehensive reform of state policy in the respective area and as an integral part of the mechanism of formation, implementation and evaluation of policies in general [7].

\subsection{Challenges of the European Union Environmental Legislation}

Analysis of the nature of the European Union laws and especially the sources according to which Ukraine has to implement commitments under the Association Agreement suggests that such implementation is different from similar processes in the European Union Member States. This is primarily due to the fact that Ukraine is not obliged to operate according to principles and mechanisms valid in the EU and applied to Member States [8].

Ukraine also does not have a clear EU membership perspective that fully makes it impossible to apply the approaches used by candidate countries. Main problems and difficulties that arise from the coordination with the implementation of EU legislation on environmental protection in Ukraine stem primarily from the legal nature of the European legislation, institutional features, and the lack of appropriate mechanisms for monitoring compliance with the European legislation in Ukraine because of technical reasons [9]. Nevertheless, this division is conditional, because the causes of certain challenges often overlap. Challenges arising from the legal nature of the EU environmental legislation may be classified into 4 main groups (Figure 3).

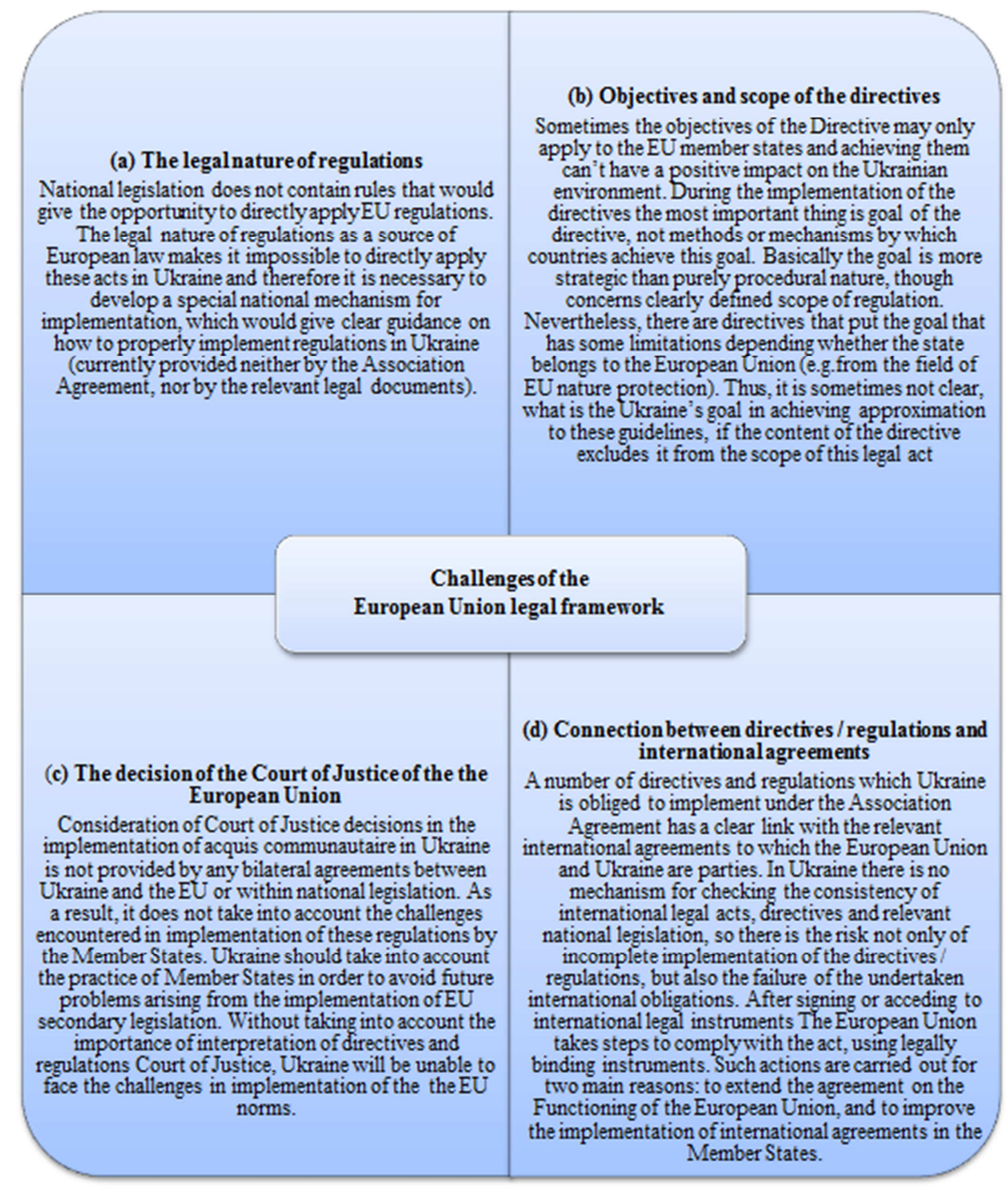

Figure 3. Challenges of the European Union legal framework. 
Ukraine's technical challenges in the approximation to EU environmental acquis consist from two main levels:

(I) Dynamism of the EU laws

EU legislation in all areas is a dynamic process. The problem for Ukraine is that the mechanism for the implementation of updates in directives or regulations is neither provided in Ukraine - EU bilateral documents (Association Agreement and others), nor in the national legislation. EU legislation is constantly being improved based on the implementation experience of Member States, European Commission reports, analysis of the implementation difficulties, emergence of new circumstances and experience of the Court of Justice [10]. The revision provisions for each legal act are provided in the text of each document. Without similar dynamic approach, Ukraine will be always "catching up" with the EU laws and will not have the proper level of implementation of legislation in the discussed area.

(II) Quality of translation

Currently, the issue of European laws' translation quality into Ukrainian is quite acute. Only accurately translated terms of European legislation or adequate substitutes ensure effective implementation of directives in Ukraine. The importance of documents' authenticity in national languages has been emphasized also by the "new" Member States. Experts in various fields and lawyers should be also engaged in official translation.

For the successful approximation of environmental legislation to the European laws, Ukraine should also manage institutional challenges (Table 1).

Table 1. Ukraine's institutional challenges in the approximation of environmental legislation to the EU acquis.

\begin{tabular}{|c|c|}
\hline Challenges & Institutional differences in EU and Ukraine \\
\hline $\begin{array}{l}\text { (I) Monitoring } \\
\text { compliance with } \\
\text { European standards }\end{array}$ & $\begin{array}{l}\text { Control function of the European Commission and the Court of Justice has an important impact on the effective implementation } \\
\text { of the secondary EU legislation provisions. Based on received information (its own initiative or Member States report), the EC } \\
\text { may conclude about alleged infringement of EU law, and launch formal investigation against a Member State, first at the } \\
\text { administrative stage and then at the Court. Court of Justice, among others, has the authority to consider claims of default, } \\
\text { including the rules of secondary law. For Ukraine, there is no control mechanism for the implementation of legal provisions, and } \\
\text { secondary EU legislation implementation is not regulated within the Association Agreement or other bilateral or national } \\
\text { documents. }\end{array}$ \\
\hline $\begin{array}{l}\text { (II) Reporting } \\
\text { mechanism }\end{array}$ & $\begin{array}{l}\text { Directives provide a reporting mechanism for Member States to the European Commission on specific measures and } \\
\text { implementation of directives and set specific timelines and procedures for submitting reports. Directive may also include a } \\
\text { requirement to report to the Commission the text of the provisions of national law which they adopt in the scope of the directive. } \\
\text { Ukraine, not being a member of the European Union has no obligation to report on the status of implementation of guidelines and } \\
\text { specific measures. This creates a problem of proper control over the implementation of the Directive and excludes the exchange } \\
\text { of experiences on issues of implementation of the directives. Reporting mechanism on the implementation of Association } \\
\text { Agreement in Ukraine is not enough - there should be a special reporting mechanism for each specific document, taking into } \\
\text { account the special status of Ukraine. }\end{array}$ \\
\hline $\begin{array}{l}\text { (III) Mutual } \\
\text { obligations of } \\
\text { Member States }\end{array}$ & $\begin{array}{l}\text { Directives establishes not only specific rules that must be reflected in national legislation, but also provide measures and } \\
\text { mechanisms of cooperation between Member States to achieve certain objectives of directive, establishing reciprocal rights and } \\
\text { duties of Member States. Several directives involve actions and measures in cooperation with other Member States at EU level or } \\
\text { special conditions for the Member States. This approach leads to asymmetric implementation and put Ukraine outside such } \\
\text { activities. Without being able to directly send reports to the European Commission, Ukraine cannot use the provisions of this } \\
\text { kind. }\end{array}$ \\
\hline $\begin{array}{l}\text { (IV) Special authority } \\
\text { under the directives / } \\
\text { regulations }\end{array}$ & $\begin{array}{l}\text { A number of guidelines provides establishment of specialized bodies that promote and assist in the implementation of Directives } \\
\text { in the Member States. Not being a member of the EU, Ukraine is not able to use the results of such bodies or be involved in their } \\
\text { work, and therefore is not able to use their results in the implementation process. }\end{array}$ \\
\hline
\end{tabular}

At this point it is also worth mentioning, that the Association Agreement between Ukraine and the EU, as well as deep economic integration between the European Union and Armenia, Georgia and Moldova through the Deep and Comprehensive Free Trade Area (DCFTA) is extended primarily for political reasons. Political elites in these countries perceive relations with the EU first of all from political and security perspectives, rather than in economic terms. Still Ukraine is undoubtedly a pioneer in terms of legal approximation in the Eastern neighborhood. The country's size and population make it a relatively important market for the EU, too (EU Directorate General for External policies, 2013).

Thirty seven orders of the Cabinet of Ministers of Ukraine on approval of 150 implementation plans for the 219 EU legislative acts have been approved. Also appropriate changes have been done to the Regulation of the Cabinet of
Ministers of Ukraine, which serve as certain "filters" to screen out regulations that do not correspond to or contradict the provisions of the Agreement. Thus, the measurement program consists of the basic document, the Action Plan for the implementation of the Association Agreement between Ukraine and the EU in 2014-2017 (Approved by the Cabinet of Ministers on 17 September 2014, № 847-p). The plan provides both organizational and normative actions. Legislative actions include detailed plan for implementation of EU laws, and describe certain actions and goals of the ministry for efficient implementation of the EU law's provisions, which must be implemented on the basis of commitments under the Association Agreement. Structure of these plans is adapted to modern analytical capabilities of Ukrainian public administration system and is based on traditional methodologies for the transposition of EU legislation into the laws of the Member States. 
The order of Verkhovna Rada (Parliament) of Ukraine provides bills for compliance with international legal obligations to the Committee for European Integration (Article 93 of the Rules). The Committee should provide its conclusions to the main committee responsible for reviewing the bill within 21 days. In practice, this provision of Regulation is almost impossible to achieve because of internal parliamentarian features and orientation of public administration mainly on legislation setting activities. In the context of legislative practice:

1) The right for legislative initiative of national deputy is actually unlimited, which is unusual for European practice;

2) There is no effective control over compliance with the Rules for registration and submission of bills; therefore the agenda of the Parliament session includes technical content and drafts of laws;

3) The deputy's right to submit bills to replace the previously submitted ones is not limited, and the Verkhovna Rada must give an opinion on all such laws, regardless of their adoption prospects.

It should be noted that for the improvement of procedures for dealing with bills for compliance with the European law national deputies have initiated amendments to the Regulations in terms of improving the mechanism approach [11]. It was expected to introduce compulsory mechanism for checking all the bills at all stages of the proceedings, including preliminary examination and consideration in the first and second readings, by:

1. Inclusion of opinion on compliance with the obligations in the field of European integration into the structure of the explanatory note to the draft law;

2. identifying additional reason for the return of the bill (without inclusion in the agenda) because of noncompliance with EU law;

3. giving additional powers to specialized committee to conduct an appropriate assessment. The introduction of this new approach would significantly improve the legislative process and ensure more effective fulfillment of international legal obligations in the field of European integration, but the bill did not receive adequate support.

Administrative capacity for the implementation of EU law is a key aspect of monitoring and evaluation carried out by the European Commission regarding all candidate countries. At this stage in the context of EU enlargement the emphasis on public administration increases. Last November the European Commission in cooperation with SIGMA program developed "Principles of Public Administration", considered as a basis for dialogue with candidate countries and potential candidates for EU accession on public administration reform.

Key requirements and principles focus on implementing the principles of transparent and effective democratic governance and effective public administration, which are a prerequisite for successful European integration [12]. Key requirements for public administration include principles directly related to the policies' implementation in the field of European integration (Table 2)

Table 2. Key requirements for public administration in Ukraine, related to environmental laws approximation.

\begin{tabular}{ll}
\hline Area of actions & Required activities \\
\hline Policy making & $\begin{array}{l}\text { Set clear horizontal procedures of the national process of European integration, compliance is ensured through coordination- } \\
\text { responsible authority } \\
\text { Pvailable harmonized medium-term planning of all processes related to European integration, integrated into domestic policy } \\
\text { planning }\end{array}$ \\
Policy implementation & $\begin{array}{l}\text { Procedures and institutional support for European integration are an integral part of the policy development process and ensure } \\
\text { timely transposition acquis. }\end{array}$ \\
\hline
\end{tabular}

It should be emphasized that the above principles are being implemented, also through the implementation of a clear legal framework. In particular, they aim to strengthen the position of Ukraine in the implementation of international legal obligations in the field of European integration one of the following alternatives (Table 3). For the selection of the most effective way it is proposed to analyze each alternative according to selected criteria.

Table 3. Analysis of alternative ways of improving the procedure of the approximation of Ukrainian environmental legislation to EU acquis.

\begin{tabular}{lll}
\hline & $\begin{array}{l}\text { Alternative 1 } \\
\text { The settlement of problematic issues that arise during } \\
\text { the implementation of the Association Agreement, } \\
\text { including approximation of laws }\end{array}$ & $\begin{array}{l}\text { Alternative 2 } \\
\text { Development and approval of a comprehensive bill on } \\
\text { issues of implementation of the Association } \\
\text { Agreement }\end{array}$ \\
\hline $\begin{array}{ll}\text { Complex or fragmented action } \\
\text { Involvement of all stakeholders }\end{array}$ & $\begin{array}{l}\text { Fragmented } \\
\text { Only executive authorities }\end{array}$ & Complex \\
Decision-making rate & Fast enough (government acts) & Public authorities \\
& & Quite a long process, depending on the position of the \\
& key political forces in Parliament (Bill) & \\
\hline
\end{tabular}

The analysis shows that the most appropriate way to increase the effectiveness of legislative approximation to EU law, including ensure effective implementation of international legal obligations in the field of European integration, is the approval of a comprehensive law.

\subsection{Developing Legal Mechanism for the Approximation of Environmental Policy Frameworks and Instruments}

For the formation of legal approximation mechanism in Ukraine, and a new coordination mechanism of Euro 
integration policy in connection with the implementation of the Association Agreement and the formation of political association and economic integration, appropriate mechanism should be holistic and comprehensive, and integrated into the existing constitutional order at all legislation levels [13]. Clearly the implementation of the Association Agreement is the core element of Ukraine's integration into the EU. Although the Agreement is the direct responsibility of public authorities, laid on them by the current legislation in the field of treaty law and other legislative acts, the Agreement itself is applicable legal act, which takes precedence over national law, but not enough to create a reliable and comprehensive legal "framework" of European integration in the Ukrainian legal field [14]. Thus for the legislation approximation in this area and improvement should be based on a number of basic approaches.

In order for comprehensive analysis when assessing compliance on the Association Agreement and the EU it is obligatory to study and reflect in the conclusion (Figure 4).

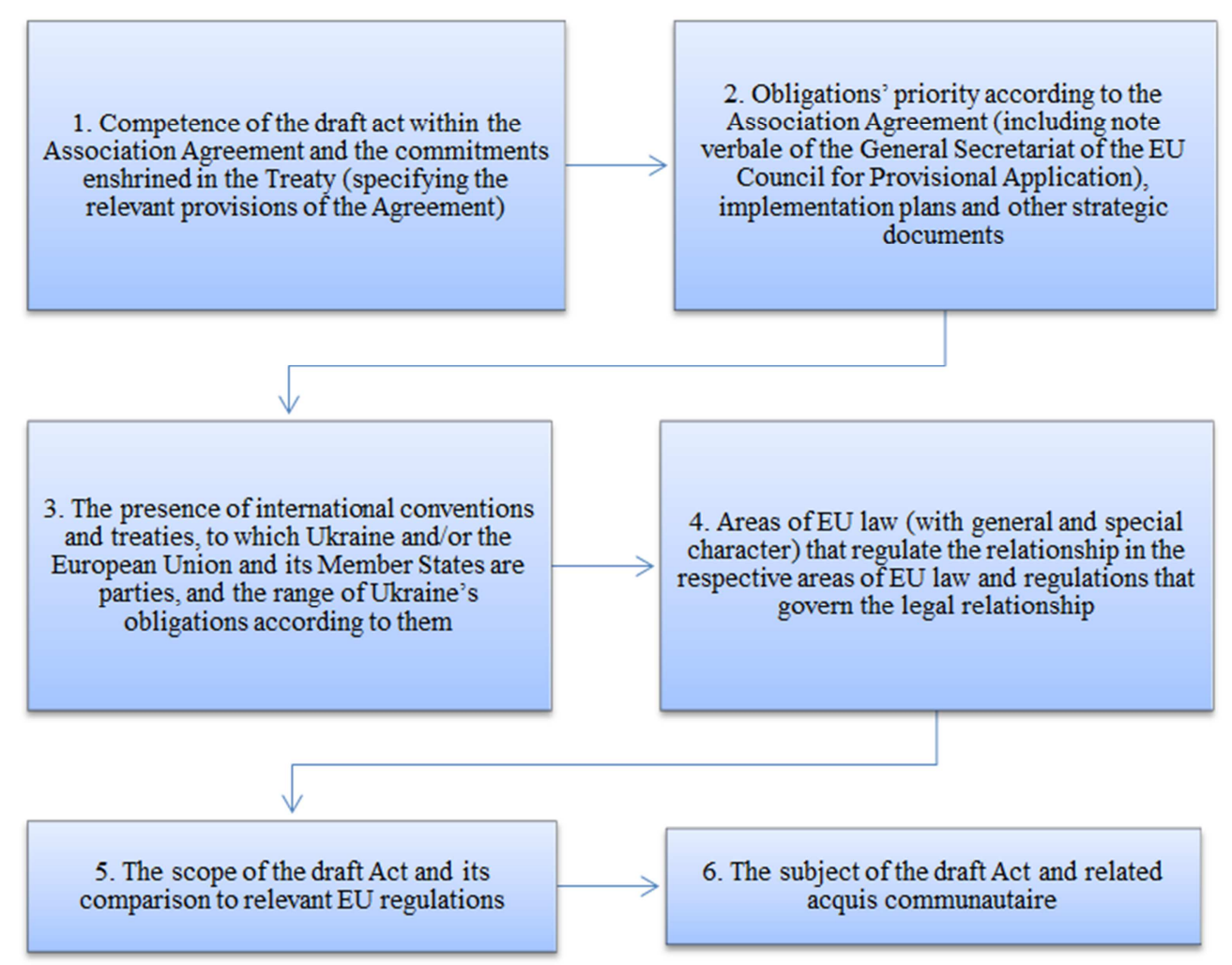

Figure 4. Stages of legal obligations compliance within the Association Agreement and the EU environmental legislation.

The results of the examination indicate whether the project corresponds to the Association Agreement, including international legal and program documents of the Cabinet of Ministers, and whether it corresponds to European Union law (EU acquis).

\section{Conclusions}

European integration should be seen not so much as foreign policy, but primarily as an internal strategy, including public policy issues in various spheres, approximation of legislation and its proper implementation and application. Another important attribute of integrity is the institutional mechanism of the Ukraine's European integration. Such mechanism should be clearly based on the Constitution, be holistic and cover all dimensions and aspects of EU policy, regulate the relevant features, and be an integral part of the current government system and mechanism of Ukrainian state. Hence, it is advisable to first establish lean principles, responsibilities and tasks of the public authorities, leaving them discretion to choose the necessary methods and tools for their implementation. In this context, a key principle in the European integration process is to ensure legal certainty, integrity and clarity of regulation, implementation of legal provisions at the appropriate legislation level, legal regulation of important relationships with significant consequences, and ensuring terminological consistency and clarity of concepts, categories and concepts to be used in the legislation.

It is also necessary to consider the concepts and categories of EU law, in particular the current wording of EU Treaties, Ukraine's international agreements on European integration, etc. Given the above, legislation should regulate the specifics of government policy and the implementation of international legal obligations for European integration and approximation of principles, including:

1. In general terms - set goals and deadlines, legislation for the European integration policy implementation, to resolve the issue of monitoring, evaluation and implementation of commitments in progress; 
2. in terms of institutional mechanism of European integration - clarify the objectives of the Verkhovna Rada of Ukraine, the Cabinet of Ministers of Ukraine, determine the order of reporting, monitoring and evaluation tools for parliamentary control, etc., and resolve complex issues related to the decisions of the association;

3 . in terms of personnel, financial and information management - to determine requirements for public employees engaged in European integration, training, skills development; financial and information security;

4. in terms of approximation of Ukrainian legislation to EU law - to determine the principles and mechanisms of gradual approximation of law, its components and their content, taking into account that the process of approximation is broader than the implementation of the Association Agreement; an integrated approach to the concept of implementation of EU law, including approximation of legislation and other policy measures (institutional, organizational, etc.); and the procedure for prioritizing actions in areas that require legislative approximation to EU law; the procedure for examination of laws and regulations for their compliance with EU law.

\section{References}

[1] Muravyov, V. (2012) Legal nature of the Association Agenda between Ukraine and the European Union. Veche, No. 8, pp. 16-21.

[2] Koch, M., Gullberg, A. T., Schoyen, M., Hvinden, B. (2016) Sustainable welfare in the EU: Promoting synergies between climate and social policies. Critical Social Policy, 2016, Vol.36 (4), pp.704-715.

[3] DIW Econ (2013) Towards a low carbon growth strategy for Ukraine: Key policy steps. Low Carbon Ukraine - Policy Paper No. 2 (April 2013) Project "Capacity Building for Low Carbon Growth in Ukraine".

[4] Botcheva, L. (2001) Expertise and International Governance: Eastern Europe and the Adoption of European Union Environmental Legislation. Global Governance, 1 April 2001, Vol.7 (2), pp.197-224.
[5] Petrov R., Kiseleva T. (2000) Approximation and Harmonization of Legislation in the Law of the European Union and International Law. The Legal Journal of Donetsk University, 2000. No. 2 (5) pp. 29-34.

[6] Petrov, R. (2013) The concept of "transposition" of law as part of the process of bringing Ukrainian legislation in line with the "acquis" of the European Union. Law of Ukraine, 2013, № 6, pp. 70-76.

[7] Nachmany, M., Fankhauser, S., Townshend, T., Collins, M., Landesman, T., Matthews, A., Pavese, C., Rietig, K., Schleifer, P., and Setze, J. (2014) The GLOBE climate legislation study: a review of climate change legislation in 66 countries. Fourth edition. London: Grantham Research Institute on Climate Change and the Environment, London School of Economics and Political Science, and GLOBE International.

[8] Braun, M. (2014). Europeanization of environmental policy in the new Europe: Beyond conditionality. Farnham, Surrey, England; Burlington. Ashgate Publishing Limited.

[9] Langlet, D. (2016) EU environmental law and policy. Oxford: Oxford University Press, 2016.

[10] Korppoo, A., Moe, A. (2008) Joint Implementation in Ukraine: national benefits and implications for further climate pacts. Climate Policy, 2008, Vol.8(3), pp.305-316.

[11] Kapios, P. J. (2002) Environmental Enlargement in the European Union: Approximation of the Acquis Communautaire and the Challenges that it Presents for the Applicant Countries. Sustainable Development Law and Policy, Spring/Summer 2002, 4-9, 20-21.

[12] Golub, J. (2005) Transnational Politics of the Environment: The European Union and Environmental Policy in Central and Eastern Europe. Perspectives on Politics, 3/2005, Vol. 3(01).

[13] Focken, H. (2015) Between national interests and the greater good: struggling towards a common European Union energy policy in the context of climate change (Global Public Policy Network Essay) Journal of International Affairs, 2015, Vol. 69 (1), p.179 (13).

[14] Duttle, T., Holzinger, K., Malang, T., Schäubli, T., Schimmelfennig, F., Winzen, T. (2016) Opting out from European Union legislation: the differentiation of secondary law. Journal of European Public Policy, 01 April 2016, p.1-23. 